\title{
THE IMPACT OF THE EU PROGRAMS IN THE WESTERN BALKANS
}

\author{
Suada Ajdarpašić \\ Gazmend Qorraj ${ }^{* *}$
}

\begin{abstract}
The aim of this study is to contribute to understanding the impact of the EU assistance on increasing institutional capacity, particularly in higher education institutions of the Western Balkans. This study highlights the hypothesis concerning the impact of EU funds in capacity building of human resources in Western Balkan countries, with particular emphasis on Kosovo, Albania, BiH, Macedonia, Serbia, Montenegro, and Croatia. An additional value added to the EU programs is university-industry cooperation which is recognized as an important factor for strengthening the research capacities, human resources, and regional cooperation between the institutions in the Western Balkans. For the Methodology, the Cronbach Alpha analysis will be proceeded to assess the accuracy of the questionnaire, followed by the research with multiple and simple linear regression. The result of the paper has shown the positive relationship between the performance of the institutions and the EU programs, therefore, the main conclusions of the paper are that EU funds positively affect the advancement of human resources in WB due to limited financial sources of the local institutions.
\end{abstract}

KEYWORDS: EU Programs, Human Capital, Performance, Western Balkans, European Union, Higher Education Institutions.

\footnotetext{
* Suada Ajdarpašić, University of Pristina, Kosovo; suada.ajdarpasic@unhz.

** Gazmend Qorraj, University of Pristina, Kosovo; gazmendqorraj@yahoo.com.
} 


\section{INTRODUCTION}

The overall aim of the paper ascertains how the EU funds have influenced the development of the capacity building of Higher Education Institutions (HEIs) in the Western Balkans respectively the development of human resources in these countries. It is crucial to analyze the impact of the EU funds, especially those in the field of education in increasing the capacity of human resources in Higher Education Institutions of WB countries taking into consideration the limited financial and human resources in these countries.

To evaluate the impact of EU funds on capacity building of human resources, the level of interconnection between the structure of the institution and the characteristics of the programs offered by the EU is determined. It is already known that there is a high demand for the EU programs, which programs will contribute to upgrade and increase the performance of the human resources, as well as the performance of the HE institutions in general.

This study assumes that there is a positive correlation between the performance of the human resources of HEIs in WB and their cooperation with the EU universities. Second, intensive cooperation between universities in the WB region is a crucial issue. Third, the previous experience of HEI staff with EU funds and programs is a very important condition for the absorption of the funds and programs. Such components will support the improvement of the institution's level structure and performance, to achieve the most productive results. Apart from the academic development and research activities, nowadays the labor market and industry cooperation it is crucial for the universities to support economic growth, social inclusion, and regional cooperation. As the paper will take into account the Western Balkans, therefore according to the study Zgaga et.al ${ }^{1}$ the specific history of the Western Balkans is also reflected in the perception of the role of higher education institutions, therefore the research shows that in the countries where the recent conflict was most serious (i.e. Kosovo, Bosnia and Herzegovina) higher education institutions are expected to contribute to the reconstruction of society more than support the economic growth.

Furthermore, the EU funds and programs could contribute in two ways: first, to influence education and economic progress of individual Western Balkan countries, and, second, to promote the establishment of networks between uni-

1 Zgaga, P., Klemenčič, M., Komljenovič, J., Miklavič, K., Repac, I. and Jakčić, V.: Higher Education in the Western Balkans: Reforms, Developments, and Trends, Centre for Education Policy Studies, Ljubljana, 2013. 
versities in the region. ${ }^{2}$ Besides, the cooperation in the sphere of education and innovation could enhance better relations between countries in the Western Balkans, especially in higher education where respective universities could commit themselves to joint study programs, promoting regular exchanges of both academics and students.

The paper is structured as follows: introduction part followed by theoretical background. Also, there will be models and empirical research, followed by the main findings and the final conclusions.

\section{THE THEORETICAL APPROACH OF HUMAN RESOURCES AND EU FUNDS}

Many authors and economists have drawn various conclusions about the importance of human resource performance in HEIs, as well as its role in promoting social prosperity and well-being. In addition to numerous studies, Varga and Vel (2010) used a New Keynesian general equilibrium model according to which their conclusion for the long-run effect is 'that the productivity-enhancing effects, among others, human capital investments become gradually stronger and generate large output effects in the long run'. ${ }^{3}$ Thus, in any organization or institution, employees are the most important part, as they contribute to its growth and success. ${ }^{4}$ On the other hand, Zeithaml V.A., Varadarajan P.R. \& Zeithaml C.P. (1988) have found that the organization, within its policies, develops various processes for research, learning and decision making, through which it is claimed to achieve a satisfactory level of performance below the norms of limited rationality. ${ }^{5}$

Currently, human resources performance is considered as a very important component for an organization or institution, therefore the organizations

2 Qorraj, G.: Economic Cooperation as a Way toward Reconciliation and EU integration for Kosovo and Serbia," in Mehmeti, Leandrit I. and Radeljic, Branislav (ed.), Kosovo and Serbia: Contested Options and Shared Consequences,(Pittsburgh, PA: University of Pittsburgh Press), 2016, pp. 196-215.

3 Paun, C.: The socio-economic impact of European funds on Eastern European countries, International Review of Social Research, Vol. 4, Issue 1, 2014, pp. 52.

4 Muslim Amin, Wan Khairuzzman Wan Ismail, Siti Zaleha Abdul Ras \& Richard Daverson Andrew Selemani: The impact of human resource management practices on performance: Evidence from a Public University, The TQM Journal, Vol. 26, No. 2, pp. 125-142 ISSN: 17542731, 2014.

5 Zeithaml V.A., Varadarajan P.R. \& Zeithaml C.P.: The Contingency Approach: Its Foundations and Relevance to Theory Building and Research in Marketing, European Journal of Marketing, Vol. 22, No. 7, 1998, pp. 37-64 
achieve high and stable performance through the work systems they adopt, but it is known that these systems are managed by human resources. Therefore, the capacities of these resources can be developed through learning at all levels to be able to support performance improvement. They are also given the opportunity to take full advantage of their abilities, where people are generally valued and rewarded according to their contribution. Furthermore, Groot and Molen ${ }^{6}$ defined the capacity building of human resources as the development of individuals' knowledge, skills, and attitudes that are important in the design, development, management, and sustainability of institutions. As it is well known, the high performance of the organization means improving performance through people or human resources. This can be done through the development and implementation of a high-performance culture that incorporates a high-performance work system in which performance management plays an important role. Therefore, people are also involved in the development of high-performance practices. Moreover, it is assumed that good human resource management practices can only increase performance if properly implemented. Based on this, the performance system is composed of several components such as performance determinants in the organizational environment, which are the work environment, employee skills and knowledge, level of motivation and reward, communication flow, and organizational culture. Otherwise, based on research conducted by Zgaga, P., et al. (2013), mobility and the transfer of experiences are the most common in higher education.

For the Western Balkans, international cooperation is an extremely important tool for increasing the performance and competitiveness of higher education institutions, but also their economies. This phenomenon is about the support of national reforms and the increase of institutional capacities. In addition the wave of internationalization that has swept over the countries in the Western Balkan region, in which countries the internationalization of higher education has been a salient political issue. ${ }^{7}$ Therefore, the internationalization of higher education is often understood in the region as a policy transfer. ${ }^{8}$

\footnotetext{
6 Groot, R., \& Molen, P.: Workshop on capacity building in land administration for development countries: final report, ITC: The Netherlands, 2000.

7 Zgaga, P., Klemencic, M., Komljenovic, J., Miklavič, K., Repac, I., \& Jakacic, V.: Higher education in the Western Balkans: reforms, development, trends. Key findings from field research. Faculty of Education, University of Ljubljana, 2013, pg. 61.

$8 \quad$ Zgaga, P., Klemencic, M., Komljenovic, J., Miklavič, K., Repac, I., \& Jakacic, V.: Higher education in the Western Balkans: reforms, development, trends. Key findings from field research. Faculty of Education, University of Ljubljana, 2013, pp. 61.
} 
One of the region's outstanding specific features is the understanding of the role of higher education in the reconstruction of a post-conflict and transitional society and economy. There is a common understanding of the constitutive role of higher education in state-building or nation-building. ${ }^{9}$

As it is known, international cooperation is realized through financial support from various international organizations, in particular EU programs such as CARDS, TEMPUS, ERASMUS+, HORIZON 2020, as well as other relevant frameworks in the field of education. While the above-mentioned programs have increased capabilities of Western Balkan countries, Horizon 2020 is an additional challenge for these countries, especially considering their limited capabilities in research and innovation. ${ }^{10}$

The authors such as Fazekas M. \& King P. (2017), EU Structural and Cohesion funds represent the prime instrument supporting development in the EU's least developed regions, hence they are essential to the cohesion of the whole EU. ${ }^{11}$ Otherwise European Funds are submitted to contribute to the development of European countries, to improve the infrastructure, to improve human resources, to boost R\&D and innovation. ${ }^{12}$

Apart from the upgrade of human resources, an additional benefit for these countries from the EU programs is their integration into various areas of cooperation between universities and industry. According to the Lisbon Strategy 2020 , the importance of a coalition between science and economy is increasing as by 2000 around $22 \%$ of jobs required a high profile of qualifications while around $29 \%$ low profile qualifications. On the contrary, it is expected that by 2020 around $35 \%$ of jobs will require a high profile of qualifications. Therefore according to the EU trends, there is a trade-off between Industry and High Technology sector.

\footnotetext{
9 Zgaga, P., Klemencic, M., Komljenovic, J., Miklavič, K., Repac, I., \& Jakacic, V.: Higher education in the Western Balkans: reforms, development, trends. Key findings from field research. Faculty of Education, University of Ljubljana, 2013, pp. 22.

10 Ajdarpašić, S. \& Qorraj G.: Does University performance matter for EU programmes in South East Europe: Case Study HORIZON 2020, Journal of Contemporary Management Issues, Volume 24, 2019, DOI: https://doi.org/10.30924/mjecmi.24.2.1, No. 2, pp. 1-10.

11 Fazekas, M., \& King, L.P.: Perils of development funding? The tale of EU Funds and grand corruption in Central and Eastern Europe, regulation \& Governance, Volume 13, Issue 3, 2019, pp. 2.

12 Paun, C.: The socio-economic impact of European funds on Eastern European countries, International Review of Social Research, Vol. 4, Issue 1, 2014, pp. 51.
} 
The impact of European Funds on economic growth or development became a research topic in the last years with interesting and conclusive results. ${ }^{13} \mathrm{Ac}-$ cording to the EU Commission Report 2011, while economic growth in hightech sector 4.1 Jobs is created in the high-tech sector is 1.4 million in particularly the case for high-tech services such as telecommunications, computer services, and research \& development. The high-tech sector, i.e. sectors with a large proportion of high-skilled jobs, representing 5.5\% of total employment and about $8 \%$ of EU's GDP in 2009 . The sector has grown much more rapidly than the rest of the economy (4.1\% versus $1.8 \%$ ) and it has created 1.4 million jobs between 1995 and 2009. Given their importance, EU funds come with strings attached, most notably enhanced bureaucratic controls, requirements of transparency, and strengthened oversight mechanisms - all aimed at preventing misuse of public money. ${ }^{14}$

However, even though member and candidate countries are eligible to apply for funds from the EU to finance research and development, competition for these resources has proven very difficult for institutions in the WB. These countries have limited resources at their disposal, to begin with, unlike developed countries that can invest significantly larger resources in the necessary expertise and infrastructure, to successfully tap into these funding streams. ${ }^{15}$ Consequently, the proportion of funding obtained from the EU in the WB is still very low, as the current funding mechanisms employed by the EU are perpetuating the status quo regarding the distribution of funds across Europe. ${ }^{16}$

While on the other hand, capacity building as a broad concept is closely linked to education, training, and human resource development. It can also refer to improvements in the ability of all employees to perform appropriate tasks within the broader set of performance standards of the organization. Finally, if initially European Union was developed as a complex agreement for common markets and for facilitating production and exchanges among members, today European Union is transformed in a financing and redistributive vehicle of wealth from more developed countries to fewer ones through the so-called

13 Paun, C.: The socio-economic impact of European funds on Eastern European countries, International Review of Social Research, Vol. 4, Issue 1, 2014, pp. 51.

14 Fazekas, M., \& King, L.P.: Perils of development funding? The tale of EU Funds and grand corruption in Central and Eastern Europe, regulation \& Governance, Volume 13, Issue 3, 2019, pp. 2.

15 Brajkovic, L.: Higher Education in Western Balkans: Recent Trends and Challenges. International Higher Education, (87), 2020, pp. 28.

16 Brajkovic, L.: Higher Education in Western Balkans: Recent Trends and Challenges. International Higher Education, (87), 2020, pp. 28. 
European Funds. The interest for public policies and rules to redistribute such wealth significantly increased in past decades ${ }^{17}$, and still continues.

\section{SAMPLE SIZE AND RESEARCH METHODOLOGY}

\subsection{SAMPLE SIZE}

The sample that was used for the empirical part consists of Western Balkans countries (Kosovo, Albania, Bosnia and Herzegovina, Macedonia, Serbia, and Montenegro), including the Republic of Croatia, for the period of 2005 - 2018. Such model allows us to use a panel evaluator to determine the statistical significance as well as the direction of the connection between the main variables, respectively: i) Human Resource Performance of HEI, ii) Cooperation with EU universities; iii) Cooperation with the universities of the region - WB; iv) Previous experience of HEI staff on EU funds and programs.

This empirical study was conducted through two questionnaires distributed to 13 Public and Private Higher Education Institutions; as well as to employees (human resources) for each institution in the Western Balkans and Croatia (see table 1). The respondents in this research are project coordinators (International Relations Office), academic and administrative staff. In general, the selection of these institutions was made based on activity similarity, as well as due to the nature of the challenges and problems they have faced or are facing.

Table 1. Sample determination - Respondents per each country

\begin{tabular}{|c|c|c|c|}
\hline Country & $\begin{array}{c}\text { Public } \\
\text { institutions }\end{array}$ & $\begin{array}{c}\text { Private } \\
\text { institutions }\end{array}$ & Employee \\
\hline Kosovo & 2 & 1 & \multirow{7}{*}{ 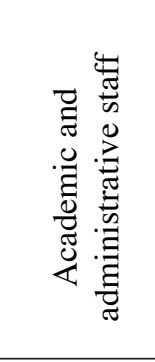 } \\
\hline Albania & 1 & - & \\
\hline $\begin{array}{l}\text { Bosnia \& } \\
\text { Herzegovina }\end{array}$ & 1 & 1 & \\
\hline Macedonia & 1 & 1 & \\
\hline Serbia & - & 1 & \\
\hline Montenegro & 1 & 1 & \\
\hline Croatia & 1 & 1 & \\
\hline Total & 7 & 6 & 100 \\
\hline
\end{tabular}

Source: Authors'.

17 Paun, C.: The socio-economic impact of European funds on Eastern European countries, International Review of Social Research, Vol. 4, Issue 1, 2014, pp. 51. 
The response rate is based on the formula presented by Neumann $(2014)^{18}$. He suggests calculating with the involvement of all respondents.

$$
\text { Total response rate }=\frac{\text { Total response rate }}{\text { Total number in the sample }- \text { inappropriate }}
$$

According to Neumann, a more common way to do this excludes unsuitable respondents and those who, despite repeated efforts, were not accessible. This is known as the percentage of active response:

\section{factive responses $=\frac{\text { Total number of answers }}{\text { Total number in the sample }-(\text { inappropriate }+ \text { inaccessible })}$}

The response rate is based on the size of the particular sample, where the actual sample size is calculated using the formula ${ }^{19}$ as follows:

$$
\boldsymbol{n}^{\mathrm{a}}=\frac{\mathbf{n} \times 100}{\mathbf{r e} \%}
$$

$\mathrm{n}^{\mathrm{a}}-$ is the actual sample size required;

$\mathrm{n}-$ is the minimum sample size;

re\% - the overall rate of responses expressed in percentage.

\subsubsection{SOCIO-DEMOGRAPHIC CHARACTERISTICS OF THE RESPONDENTS}

According to statistics, the participation of $\mathrm{HR}$ resulted as below (see table 2): 4 respondents are from the University of Pristina, 3 from AAB College, 5 from the University of Novi Pazar, 11 from the University of Tirana, 8 from the University of Peja, 3 from the International University of Travnik, 6 from the South East European University, 4 from the College of Economics, Entrepreneurship and Management, 6 from the Mediterranean University, 23 from the University of Montenegro, 6 from the University of Tuzla, 6 from the University Kliment Ohridski, and 15 from the University of Zagreb.

\footnotetext{
18 Neuman, W.L.: Social Research Methods: Qualitative and Quantitative Approaches, $7^{\text {th }}$ Edition, (Pearson, London), 2014.

19 Saunders M, Lewis Ph. \& Thornill: Research Methods for Business Students, Fifth Edition, (Pearson Education Limited, 2009), 2009.
} 
Whereas in terms of the age group of respondents, 27 respondents are 25-34 years old, 33 respondents are 35-44 years old, 24 are 45-54 years old, 14 are 55-64 years old and 2 are under 25 years old. While in terms of the level of education, we can see that 7 respondents are with the Master's level, 73 have $\mathrm{Ph} . \mathrm{D}$. level, 19 are $\mathrm{Ph} . \mathrm{D}$. candidates and 1 belongs to another qualification. On the other hand, when we talk about job positions, the data showed that there are 2 respondents in the position of project coordinator, 66 are in the position of lecturers, 28 are assistants and 4 are administrative staff. 75 of them work in public institutions, 19 in private, and 6 of them in public-private. The data also showed that 82 of the respondents were involved in EU projects, while 18 of them were not. 76 of them state that they have participated in 1-5 projects, 17 of them in 5-10 projects, 1 in more than 100 projects, 1 in more than 20 projects, 4 in more than 40 projects, and 1 in 5 national projects. 
Table 2. General information of respondents

\begin{tabular}{|c|c|c|}
\hline Higher Education Institutions & $\mathbf{N}$ & $\%$ \\
\hline University of Pristina, Kosovo & 4 & 4.0 \\
\hline AAB College, Kosovo & 3 & 3.0 \\
\hline University of Novi Pazar, Serbia & 5 & 5.0 \\
\hline University of Tirana, Albania & 11 & 11.0 \\
\hline University of Peja, Kosovo & 8 & 8.0 \\
\hline International University of Travnik, BIH & 3 & 3.0 \\
\hline South East European University, Macedonia & 6 & 6.0 \\
\hline $\begin{array}{c}\text { College of Economics, Entrepreneurship and Management, } \\
\text { Zrinski/Croatia }\end{array}$ & 4 & 4.0 \\
\hline University Mediterranean, Montenegro & 6 & 6.0 \\
\hline University of Montenegro, Montenegro & 23 & 23.0 \\
\hline $\begin{array}{c}\text { University of Tuzla, BIH } \\
\end{array}$ & 6 & 6.0 \\
\hline University of Kliment Ohridski, Bitola/Macedonia & 6 & 6.0 \\
\hline University of Zagreb, Croatia & 15 & 15.0 \\
\hline Age & $\mathbf{N}$ & $\%$ \\
\hline $25-34$ & 27 & 27.0 \\
\hline $35-44$ & 33 & 33.0 \\
\hline $45-54$ & 24 & 24.0 \\
\hline $55-64$ & 14 & 14.0 \\
\hline Under 25 & 2 & 2.0 \\
\hline Level of education & $\mathbf{N}$ & $\%$ \\
\hline Master & 7 & 7.0 \\
\hline PhD & 73 & 73.0 \\
\hline PhD candidate & 19 & 19.0 \\
\hline Other & 1 & 1.0 \\
\hline Current position? & $\mathbf{N}$ & $\%$ \\
\hline Project coordinator & 2 & 2.0 \\
\hline Lecturer & 66 & 66.0 \\
\hline Assistant & 28 & 28.0 \\
\hline Administrative staff & 4 & 4.0 \\
\hline Institution? & $\mathbf{N}$ & $\%$ \\
\hline Public University & 75 & 75.0 \\
\hline Private University & 19 & 19.0 \\
\hline Public-Private University & 6 & 6.0 \\
\hline Have you ever been involved in EU Programs? & $\mathbf{N}$ & $\%$ \\
\hline $\begin{array}{c}\text { Yes } \\
\end{array}$ & 82 & 82.0 \\
\hline No & 18 & 18.0 \\
\hline How many projects have you participated in? & $\mathbf{N}$ & $\%$ \\
\hline $1-5$ & 76 & 76.0 \\
\hline $5-10$ & 17 & 17.0 \\
\hline More then 10 & 1 & 1.0 \\
\hline More then 20 & 1 & 1.0 \\
\hline Other: 40 & 4 & 4.0 \\
\hline Other: 5 national projects & 1 & 1.0 \\
\hline
\end{tabular}


The first hypothesis has only one independent factor, while the second has more than one factor and normally there are differences!

\subsection{METHODOLOGY}

The process of data collection for this case study was conducted through the survey respectively questionnaires, to proceed further with the statistical and comparative method.

The survey method is one of the most appropriate methods to reach the required answers. However, this method is not always reliable. Therefore, to ensure that the questionnaire is valid and reliable, we have used the reliability test, or otherwise called the Cronbach Alfa coefficient. Cronbach Alfa is an instrument for measuring the reliability or consistency of data. As a function it can be noted:

$$
\alpha=\frac{N \cdot \bar{c}}{\bar{v}+(N-1) \cdot \bar{c}}
$$

\section{$\mathbf{N}$ - is equal to the number of elements; \\ c - Average covariance between elements; \\ $v-$ is equal to the mean variance.}

To implement the research, researchers start with a theoretical problem. ${ }^{20}$ The survey strategy is usually accompanied by a deductive approach. The same enables quantitative data to be collected which can be analyzed quantitatively using descriptive and inferential statistics. ${ }^{21}$

Implementing research also requires good organization. ${ }^{22}$ During the research, all the factors that play an important role in the realization of the questionnaire should be taken into account, such as complexity, costs, time, management of the process of completing the questionnaires, data recording, data interpretation, etc. Therefore, based on the wide complexity, the questionnaire was drafted in order to gather accurate information related to the topic presented.

20 Neuman, W.L.: Social Research Methods: Qualitative and Quantitative Approaches, $7^{\text {th }}$ Edition, (Pearson, London), 2014.

21 Saunders M, Lewis Ph. \& Thornill: Research Methods for Business Students, Fifth Edition, (Pearson Education Limited, 2009.

22 Neuman, W.L.: Social Research Methods: Qualitative and Quantitative Approaches, $7^{\text {th }}$ Edition, (Pearson, London), 2014. 
The standard questionnaire with tested validity and reliability was used, while multiple and simple linear regression was used to predict the performance of the institution and human resources. Considering that this study is focused on HEIs, the questionnaire was distributed to universities in WB countries, where the participants were the officials for International Cooperation as well as staff (teachers, assistants, officials, etc.). In general, respondents were individuals who have been or are involved in programs offered by the EU, otherwise, programs that have contributed to their professional development.

The compilation and structuring of the questionnaires are based on several similar studies conducted by European Commission $(2018)^{23}$, Teichler U. $(1998)^{24}$, Technopolis Group (2014) ${ }^{25}$, Neuman, W.L. (2014) ${ }^{26}$, Grant Thornton Services $(2017)^{27}$. In this study we used 2 questionnaires:

Questionnaire 1: deals with the issues of the institutions in general, or the evaluation of the performance of the institutions, as well as the contribution of the EU programs in the increase of the institutional capacities. This questionnaire is structured in 3 parts:

- Review of the institutional performance;

- General perception on EU programs for HEIs in WB;

- Contribution of programs to HEIs in WB.

Questionnaire 2: is related to the staff of higher education institutions, their experience with the funds and programs offered by the EU. Also, this questionnaire consists of 3 parts:

- Personal data of the respondents;

- Characterization of participation in EU programs;

- Motivation as a result of participation in EU programs.

23 European Commission: Instrument for Pre-Accession Assistance (IPA II) 2014 -2020, Multy - Country EU support to the Western Balkans Youth Window under ERASMUS+, 2018.

24 Teichler U.: Higher Education and Graduate Employment in Europe: Survey of Graduates in... (NatCat); Revise Master Questionnaire, 1998.

25 Technopolis Group: Assessment of the performance and impact of the first programme of the European \& Developing Countries Clinical Trials Partnership (EDCTP), 2014.

26 Neuman, W.L. (2014), Social Research Methods: Qualitative and Quantitative Approaches, $7^{\text {th }}$ Edition, (Pearson, London).

27 Grant Thornton Services: Mid-term evaluation of ERASMUS+ (2014-2020) and the predecessor programmes (more specifically the Lifelong Learning Programme and Youth in Action Programmes; Ref. Ares (2017) 5131605-20/10/2017, 2017. 


\section{RESULTS OF THE EMPIRICAL ANALYSIS AND DISCUSSIONS}

The reliability coefficient called Cronbach Alpha is the instrument for measuring data consistency. The interpretation of this coefficient would be:

- If the value obtained is $0.00 \leq \alpha \leq 0.40$, the factor gauge is not reliable;

- If the value obtained is $0.40 \leq \alpha \leq 0.60$, the reliability level of the measuring factor is low;

- If the value obtained is $0.50 \leq \alpha \leq 1.0$, the reliability level of the measuring factors is high.

The $(\alpha)$ coefficient of reliability results varies from 0 to 1 , providing an overall assessment of measurement reliability. If all points of the scale are completely independent of each other or otherwise do not correlate them or do not share any covariance, then $\alpha=0$. Also, if all points have high covariance, $\alpha$ will approach the number 1 , as the number of points on the scale approaches infinity. In other words, the higher the $\alpha$ coefficient, the more points the covariance has divided.

Table 3. Overall reliability coefficient for Higher Education Institutions

\begin{tabular}{|c|c|c|c|}
\hline \multicolumn{4}{|c|}{ Case Processing Summary } \\
\hline & & $\mathrm{N}$ & $\%$ \\
\hline \multirow{3}{*}{ Cases } & Valid & 13 & 100.0 \\
\hline & Excluded $^{\text {a }}$ & 0 & 0.0 \\
\hline & Total & 13 & 100.0 \\
\hline
\end{tabular}

\begin{tabular}{|c|c|}
\hline \multicolumn{2}{|c|}{ Reliability Statistics } \\
\hline Cronbach Alpha & N of Items \\
\hline $\mathbf{0 . 8 6 5}$ & 108 \\
\hline
\end{tabular}

Source: own analysis. 
Table 4. Overall reliability coefficient for Human Resources

\begin{tabular}{|c|c|c|c|}
\hline \multicolumn{4}{|c|}{ Case Processing Summary } \\
\hline & & $\mathrm{N}$ & $\%$ \\
\hline \multirow[t]{3}{*}{ Cases } & Valid & 99 & 99.0 \\
\hline & Excluded a & 1 & 1.0 \\
\hline & Total & 100 & 100.0 \\
\hline
\end{tabular}

\begin{tabular}{|c|c|}
\hline \multicolumn{2}{|c|}{ Reliability Statistics } \\
\hline Cronbach Alpha & N of Items \\
\hline 0.929 & 66 \\
\hline
\end{tabular}

Source: Own analysis.

The results of our research have shown that there is a high level of consistency between variables. Table 5 shows the level of reliability of the impact of EU programs on the performance of the institution which turned out to be 0.865 , while for Human Resources 0.929.

\subsection{HYPOTHESIS TESTING}

\subsubsection{HYPOTHESIS I}

According to the study of SPHERE conducted on 2017, the Regional intra WB research and higher education collaboration stimulate competition for excellence in the region and reflect national-level priorities, therefore stimulate intraregional research and HE collaboration integration and synergies, as some of the systems are too small to develop research capacities and full HE systems at the national level.

" $H_{1}$ - The cooperation of the local Universities in the WB with the EU universities has a positive effect on the increase of the opportunities for participation in the EU Programs. „The analysis of simple linear regression is presented in the below table, with certain variables which have served to verify an impact on the benefit of the EU programs. 
Table 5. Simple linear regression analysis $-\mathbf{H}_{1}$

\begin{tabular}{|l|l|l|l|l|}
\hline Independent variable & \multicolumn{4}{l|}{ Model 1 } \\
\hline & B & S.H. & $\beta$ & Sig. \\
\hline Liaison of local institutions & -0.087 & 0.107 & -0.082 & 0.419 \\
\hline $\mathrm{R}$ & 0.082 & & \\
\hline $\mathrm{R}^{2}$ & 0.007 & \\
\hline$\Delta \mathrm{R}^{2}$ & -0.003 & \\
\hline $\mathrm{F}$ & 0.658 & \\
\hline ANOVA (Sig.) & $\mathbf{0 . 4 1 9}$ \\
\hline Dependent variable: Participation in EU funds \\
\hline
\end{tabular}

Source: Authors' own calculation. 
Table 6. Simple linear regression model $-\mathbf{H}_{1}$

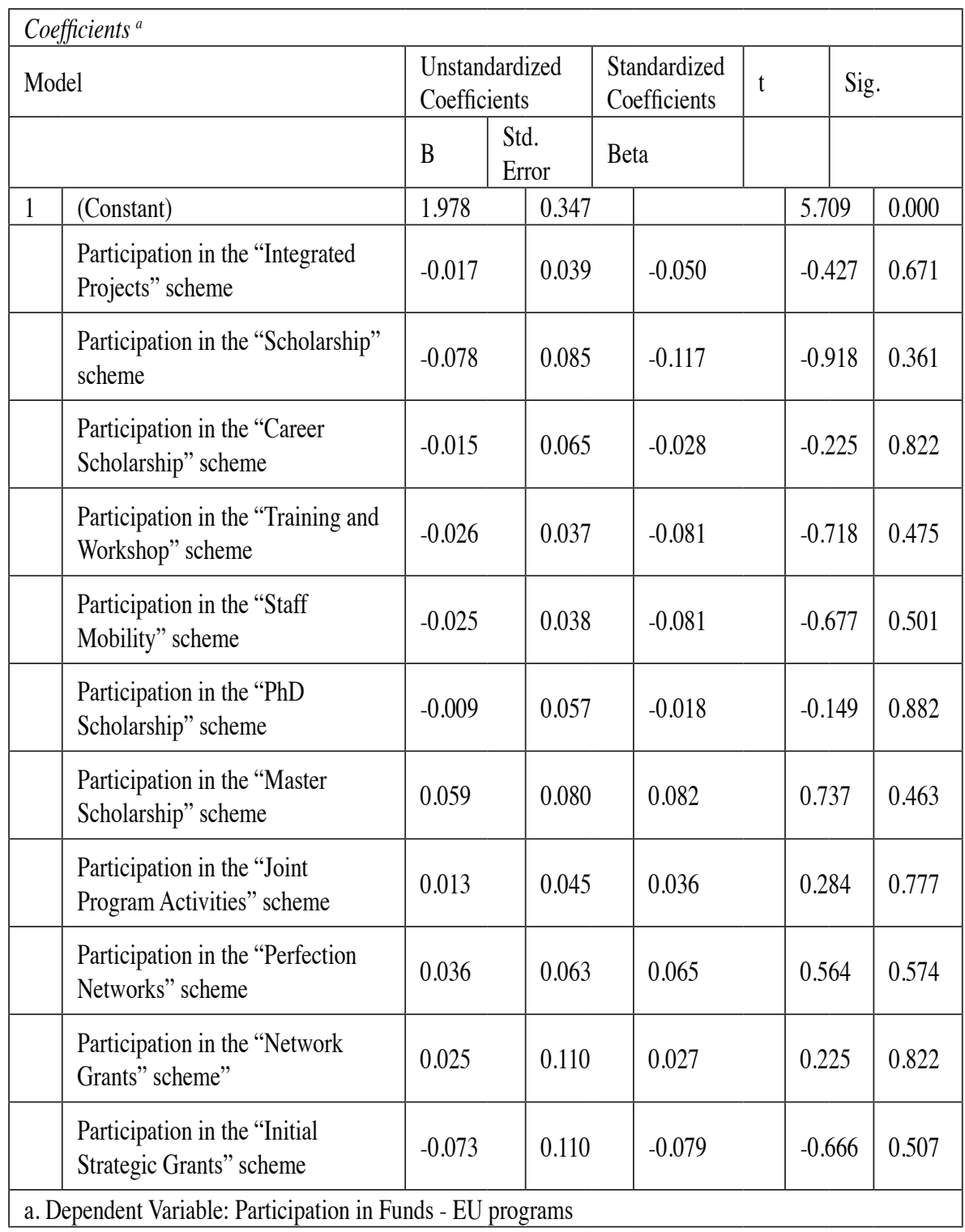

Source: Authors'.

The variable, "Liaison of local institutions" has been transformed into a group of variables of participation in program schemes, where based on the above results, there is shown that in "Liaison of local institutions" there is a positive 
correlation $(\mathrm{R}=0.082)$ but not significant, and a positive regression $\left(\mathrm{R}^{2}=\right.$ $0.007)$ but not significant, $\left(\Delta \mathrm{R}^{2}=-0.003\right)$ negative, with a high positive coefficient $(F=0.658)$ and significance $(\beta=-0.082, p>0.05)$ which means that the liaison of local institutions of WB with EU universities has a positive impact on increasing the opportunities for participation in EU Programs, but statistically it is not significant.

\subsubsection{HYPOTHESIS II}

According to Stojanoska (2012), the strategic objective of EU Funds is "to foster the development of human resources, in particular by improving the quantity and quality of human capital, leading to better jobs, higher growth and development and the increased national competitiveness at international level. Furthermore, the second hypothesis is:

" $\mathrm{H}_{2}$ - The EU funds have a positive impact on the advancement of human resources in beneficiary countries". In the table below are presented the analysis of multiple linear regressions, analyzing the impact of EU funds on the advancement of human resources in WB.

Table 7. Multiple linear regression analysis $-\mathbf{H}_{2}$

\begin{tabular}{|c|c|c|c|c|}
\hline \multirow[t]{2}{*}{ Independent variable } & \multicolumn{4}{|c|}{ Model 1} \\
\hline & $\mathrm{B}$ & S.H. & $\beta$ & Sig. \\
\hline Participation in the EU program "On staff benefit" & -1.935 & 0.504 & -1.862 & 0.006 \\
\hline $\begin{array}{l}\text { Have you participated in the EU program "For the } \\
\text { benefit of students and youth"? }\end{array}$ & 1.514 & 0.410 & 1.457 & 0.008 \\
\hline $\begin{array}{l}\text { Have you participated in the EU program "For the } \\
\text { benefit of the institution"? }\end{array}$ & 1.097 & 0.301 & 0.977 & 0.008 \\
\hline $\begin{array}{l}\text { Have you participated in the EU program "For the } \\
\text { exchange of good practices"? }\end{array}$ & -2.005 & 0.481 & -1.786 & 0.004 \\
\hline $\begin{array}{l}\text { Participation in the EU program "To learn new } \\
\text { skills" }\end{array}$ & 1.125 & 0.410 & 1.083 & 0.029 \\
\hline $\mathrm{R}$ & \multicolumn{4}{|c|}{$0.875^{\mathrm{a}}$} \\
\hline $\mathrm{R}^{2}$ & \multicolumn{4}{|c|}{0.766} \\
\hline$\Delta \mathrm{R}^{2}$ & \multicolumn{4}{|c|}{0.766} \\
\hline $\mathrm{F}$ & \multicolumn{4}{|c|}{4.586} \\
\hline ANOVA (Sig.) & \multicolumn{4}{|c|}{0.036} \\
\hline
\end{tabular}

Source: Authors'. 
Based on the above results, it is shown that in the first variable "participation in the program for staff benefit", we have $(\beta=-1.862, p<0.1)$, then to "student and youth program participation", we have the coefficients $(\beta=-1.457$, $p$ $<0.1)$, to "program for the benefit of the institution" $(\beta=0.977, p<0.1)$, in the program "for the exchange of good practices" there is the coefficients $(\beta=$ $-1.786, \mathrm{p}<0.1$ ) and in the program "to learn new skills" there is coefficients $(\beta=-1.083, p<0.05)$, and in the program "to learn new skills" the coefficients ( $\mathrm{R}=0.875)$, and high positive regression $\left(\mathrm{R}^{2}=0.766\right),(\Delta \mathrm{R}=-0.766)$, with high positive coefficient $(\mathrm{F}=4.586)$ and significance $(\mathrm{P}$ value $=0.03<0.05$ $\%$ ). From these results it is shown that the variable EU funds have a positive impact on the advancement of human resources in beneficiary countries is statistically significant.

Table 8. Multiple linear regression model $-\mathbf{H}_{2}$

\begin{tabular}{|l|l|l|l|l|l|l|}
\hline \multicolumn{2}{|l|}{ Model } & \multicolumn{2}{|l|}{$\begin{array}{l}\text { Unstandardized } \\
\text { Coefficients }\end{array}$} & $\begin{array}{l}\text { Standardized } \\
\text { Coefficients }\end{array}$ & $\mathrm{t}$ & Sig. \\
\hline \multicolumn{2}{|l}{} & $\mathrm{B}$ & $\begin{array}{l}\text { Std. } \\
\text { Error }\end{array}$ & Beta & & \\
\hline 1 & $\begin{array}{l}\text { (Constant) } \\
\text { Participation in the } \\
\text { EU program "On } \\
\text { staff benefit" }\end{array}$ & -1.935 & 0.504 & -1.862 & -3.840 & 0.006 \\
\hline $\begin{array}{l}\text { Participation in } \\
\text { the EU program } \\
\text { "For the benefit of } \\
\text { students and youth" }\end{array}$ & 1.514 & 0.410 & 1.457 & 3.694 & 0.008 \\
\hline $\begin{array}{l}\text { Participation in } \\
\text { the EU program } \\
\text { "For benefit of the } \\
\text { institution" }\end{array}$ & 1.097 & 0.301 & 0.977 & 3.650 & 0.008 \\
\hline $\begin{array}{l}\text { Participation in the } \\
\text { EU program "For } \\
\text { the exchange of } \\
\text { good practices" }\end{array}$ & -2.005 & 0.481 & -1.786 & -4.169 & 0.004 \\
\hline $\begin{array}{l}\text { Participation in the } \\
\text { EU program "To } \\
\text { learn new skills"? }\end{array}$ & 1.125 & 0.410 & 1.083 & 2.745 & 0.029 \\
\hline a. Dependent Variable: Performance of Human Resources at HEIs & & & \\
\hline
\end{tabular}

Source: Authors 'own calculations. 


\subsubsection{HYPOTHESIS III}

According to the Regional Cooperation Council's Balkan Barometer 2015, around $76 \%$ of citizens in the region expect that improved regional cooperation can positively affect the economy, education, and governance. The Regional School of Public Administration (RESPA) supported by the European Union, in Montenegro, in 2010 improved regional cooperation in public administration, and strengthens administrative capacities in line with EU integration processes. Based on these findings we continued with the third hypothesis.

" $\mathrm{H}_{3}$ - Regional cooperation in WB between HEIs has a positive impact on the absorption of the EU funds, respectively the positive performance of Human Resources"

To analyze the following hypothesis we used simple linear regression wherein the following table the results of this analysis are presented as:

Table 9. Simple linear regression analysis $-\mathrm{H}_{3}$

\begin{tabular}{|l|l|l|l|l|}
\hline Independent variables & \multicolumn{4}{l|}{ Model 1 } \\
\hline & B & S.H. & $\beta$ & Sig. \\
\hline $\begin{array}{l}\text { Regional cooperation between WB and } \\
\text { HEIs }\end{array}$ & 0.137 & 0.213 & 0.190 & 4.865 \\
\hline $\mathrm{R}$ & 0.190 & & \\
\hline $\mathrm{R}^{2}$ & 0.036 \\
\hline$\Delta \mathrm{R}^{2}$ & -0.051 & \\
\hline $\mathrm{F}$ & 0.413 \\
\hline ANOVA (Sig.) & $\mathbf{0 . 5 3 3}$ \\
\hline Dependent variable: Human resource performance \\
\hline
\end{tabular}

Source: Authors'.

Based on the above results, we notice that in the first variable "Regional cooperation between WB and HEIs" there is a positive correlation $(\mathrm{R}=0.190)$ but not significant, and a positive regression $(\mathrm{R} 2=0.036)$ but not significant, $(\Delta \mathrm{R} 2$ $=-0.051)$ negative, with a positive coefficient $(\mathrm{F}=0.413)$ and significance $(\beta$ $=0.137, \mathrm{p}>0.05)$ which means that the variable Regional Cooperation in WB between HEIs positively affects the absorption of EU funds respectively the positive performance of Human Resources statistically it is not significant. 
Table 10. Simple linear regression analysis $-\mathbf{H}_{3}$

\begin{tabular}{|c|c|c|c|c|c|c|}
\hline \multicolumn{2}{|c|}{$\begin{array}{l}\text { Coefficients }^{a} \\
\text { Model }\end{array}$} & \multicolumn{2}{|c|}{$\begin{array}{c}\text { Unstandardized } \\
\text { Coefficients }\end{array}$} & \multirow{3}{*}{$\begin{array}{c}\begin{array}{c}\text { Standardized } \\
\text { Coefficient }\end{array} \\
\text { Beta }\end{array}$} & \multirow{3}{*}{$\begin{array}{c}\mathrm{t} \\
4.018 \\
\end{array}$} & \multirow{3}{*}{$\begin{array}{c}\text { Sig. } \\
0.007\end{array}$} \\
\hline & & \multirow{2}{*}{$\begin{array}{c}\text { B } \\
3.244 \\
\end{array}$} & \multirow{2}{*}{$\begin{array}{c}\begin{array}{c}\text { Std. } \\
\text { Err }\end{array} \\
0.807 \\
\end{array}$} & & & \\
\hline 1 & (Constant) & & & & & \\
\hline & $\begin{array}{l}\text { Are the Grants } \\
\text { for collaborative } \\
\text { projects offered } \\
\text { through EU } \\
\text { programs relevant } \\
\text { to your needs? }\end{array}$ & -0.498 & 0.304 & -0.796 & -1.634 & 0.153 \\
\hline & $\begin{array}{l}\text { Are Grants for } \\
\text { Single Beneficiary } \\
\text { Projects through } \\
\text { EU Programs } \\
\text { relevant to your } \\
\text { Needs? }\end{array}$ & 0.419 & 0.746 & 0.675 & 0.562 & 0.595 \\
\hline & $\begin{array}{l}\text { Are financial } \\
\text { instruments (e.g. } \\
\text { loans, guarantees) } \\
\text { relevant to your } \\
\text { needs? }\end{array}$ & -0.168 & 0.543 & -0.350 & -0.310 & 0.767 \\
\hline & $\begin{array}{l}\text { Is Public } \\
\text { Procurement } \\
\text { provided through } \\
\text { EU programs } \\
\text { relevant to your } \\
\text { needs? }\end{array}$ & 0.183 & 0.248 & 0.383 & 0.739 & 0.488 \\
\hline & $\begin{array}{l}\text { Are the prices } \\
\text { offered through EU } \\
\text { programs relevant } \\
\text { to your needs? }\end{array}$ & 0.090 & 0.255 & 0.188 & 0.353 & 0.736 \\
\hline & $\begin{array}{l}\text { Are the Co- } \\
\text { financing (e.g. } \\
\text { ERA-NET) } \\
\text { provided through } \\
\text { EU programs } \\
\text { relevant to your } \\
\text { needs? }\end{array}$ & 0.012 & 0.229 & 0.025 & 0.052 & 0.960 \\
\hline
\end{tabular}

Source: Authors'. 
The presented variables have shown that in none of the cases there was not found statistically significant that interrelationship between regional cooperation and HEIs can positively affect the performance of human resources.

\section{CONCLUSIONS AND RECOMMENDATIONS}

The EU continuously supported countries of the Western Balkans, as these countries face limited administrative, human, and financial resources. The EU, with its policies and strategies, creates opportunities for the prosperity and sustainability of educational institutions, both for member states and countries within the enlargement process.

The purpose of this study is to analyze the impact of various EU funds, respectively educational programs on increasing the capacity of human resources at HEIs.

Previous experience has shown that EU funds have a positive impact on increasing the capacity of Human Resources in HEIs if there are efficient and coordinated institutions with adequate absorption capabilities

The analysis of these institutions was carried out in two phases, wherein the first phase of the questionnaire on the performance of HEIs was implemented and in the second phase the questionnaire on the performance of the Human Resources of these universities.

The findings of our research strongly support the hypotheses presented, as well as confirm the proposed model, showing that in all Higher Education Institutions there is a positive relationship between the performance of the institution and the EU programs, but not at all components.

- The first hypothesis "H1 - "Cooperation of the local institutions in WB countries with EU universities has a positive effect on increasing the opportunities for participation in funds or EU programs" is statistically not significant therefore such connection can increase the opportunity to participate in EU programs, especially for the WB countries.

- The second hypothesis "H2 - EU funds positively affect the advancement of human resources in beneficiary countries" is statistically significant, therefore these funds can positively affect the advancement of human resources which has shown that our hypothesis is fully proven.

- The third hypothesis "H3 - Regional Cooperation between HEIs in WB between has a positive impact on the absorption of EU funds, respectively the positive performance of Human Resources" is statistically not significant therefore regional cooperation between HEIs in WB may affect the absorption of such funds. 
Although our hypotheses have not been fully confirmed, therefore the EU Funds can have a positive impact on the advancement of human resources, but also on the WB institutions due to limited capabilities of these countries.

Furthermore, the success of higher education-oriented EU funds depends largely on absorption capabilities implementation and allocation, where participation in these funds enables; therefore the main recommendations are as follow:

- Increase the performance of HEI institutions;

- Increase of technical capacities that influences the creation of the basis for the increase of research activities and scientific work;

- Increase the quality of scientific research activities and the scientific community in Western Balkans;

- Promoting advanced science which impacts the advancement of education and research activities,

- Creating a sustainable education system that supports quality assurance mechanisms;

- Creating opportunities for an institutional development that helps to create the basis for the development of human resources;

- Creating as many collaborations with international partners as possible, which has a positive impact as it creates the opportunity to exchange new ideas and knowledge, new experiences, exchange effective practices, etc.

\section{LITERATURE}

1. Ajdarpašić, S. \& Qorraj G.; Does University performance matter for EU programmes in South East Europe: Case Study HORIZON 2020, Management Journal of Contemporary Management Issues, Volume 24, No. 2, 2019, pp. 1-10.

- DOI: https://doi.org/10.30924/mjcmi.24.2.1

2. Angrist, J., \& Krueger, A.: Empirical strategies in labour economics: Handbook of Labour economics, Amsterdam, Elsevier, 1999.

-DOI: https://doi.org/10.1016/S1573-4463(99)03004-7

3. Brajkovic, L.: Higher Education in Western Balkans: Recent Trends and Challenges. International Higher Education, (87), 27-29, 2020.

- DOI: https://doi.org/10.6017/ihe.2016.87.9512

4. Biljana Stojanoska: Contribution of the EU funds on Development of the Republic of Macedonia. FES, 2012. 
5. Belloni, R.: Western Balkans Transitions and the Role of the European Union: In the Rise and Fall of Peacebuilding in the Balkans, Palgrave Macmillan, Cham, 2020.

- DOI: https://doi.org/10.1007/978-3-030-14424-1_6

6. European Commission: Instrument for Pre-Accession Assistance (IPA II) 2014 2020, Multy-Country EU support to the Western Balkans Youth Window under ERASMUS+, 2018.

7. Fazekas, M., \& King, L.P.: Perils of development funding? The tale of EU Funds and grand corruption in Central and Eastern Europe, regulation \& Governance, Volume 13, Issue 3, 2019, pp. 405-430.

- DOI: https://doi.org/10.1111/rego.12184

8. Grant Thornton Services: Mid-term evaluation of ERASMUS+ (2014-2020) and the predecessor programmes (more specifically the Lifelong Learning Programme and Youth in Action Programmes; Ref. Ares (2017) 5131605-20/10/2017.

9. Groot, R., \& Molen, P.: Workshop on capacity building in land administration for development countries: final report, ITC: The Netherlands, 2000.

10. Muslim Amin, Wan Khairuzzman Wan Ismail, Siti Zaleha Abdul Ras \& Richard Daverson Andrew Selemani: The impact of human resource management practices on performance: Evidence from a Public University, The TQM Journal, Vol. 26 No. 2, 2014, pp. 125-142.

- DOI: https://doi.org/10.1108/TQM-10-2011-0062

11. Neuman, W. L.: Social Research Methods: Qualitative and Quantitative Approaches, 7th Edition, (Pearson, London), 2014.

12. Paun, C.: The socio-economic impact of European funds on Eastern European countries, International Review of Social Research, Vol. 4, Issue 1, pp. 49-56, 2014.

- DOI: https://doi.org/10.1515/irsr-2014-0004

13. Qorraj G.: Economic Cooperation as a Way toward Reconciliation and EU integration for Kosovo and Serbia," in Mehmeti, Leandrit I. and Radeljic, Branislav (ed.), Kosovo and Serbia: Contested Options and Shared Consequences, (Pittsburgh, PA: University of Pittsburgh Press), 2016, pp. 196-215.

- DOI: https://doi.org/10.2307/j.ctt1qv5n21.16

14. RCC. Balkan Barometer 2015. Public Opinion Survey, Analytical report. (available at http://rcc.int/pubs_archive).

15. Regional Cooperation Council (RCC). South East Europe 2020. Jobs and prosperity in a European perspective, November, 2013.

16. Saunders M, Lewis Ph. \& Thornill: Research Methods for Business Students, Fifth Edition, (Pearson Education Limited), 2009.

17. SPHERE: Support and Promotion for Higher Education Reform Experts, Harnessing the potential in the Western Balkans. Report, 2017. 
18. Technopolis Group: Assessment of the performance and impact of the first programme of the European \& Developing Countries Clinical Trials Partnership (EDCTP), 2014.

19. Teichler U.: Higher Education and Graduate Employment in Europe; Survey of Graduates in... (NatCat); Revise Master Questionnaire, 1998.

20. Zeithaml V.A., Varadarajan P.R. \& Zeithaml C.P.: The Contingency Approach: Its Foundations and Relevance to Theory Building and Research in Marketing, European Journal of Marketing, Vol. 22, No. 7, 1988, pp. 37-64.

- DOI: https://doi.org/10.1108/EUM0000000005291

21. Zgaga, P., Klemenčič, M., Komljenovič, J., Miklavič, K., Repac, I. and Jakčić, V.: Higher Education in the Western Balkans: Reforms, Developments, and Trends, Ljubljana: Centre for Education Policy Studies. 2013. 